\title{
La violencia contra lo sagrado. Profanación y sacrilegio: una tipología
}

\section{Violence against the sacred. Profanation and sacrilege: a typology}

\author{
Manuel Delgado \\ Universitat de Barcelona \\ manueldelgadoruiz@ub.edu \\ Sarai MARTín LÓPEZ \\ Universitat de Barcelona \\ saraimarlopez@gmail.com
}

Fecha de recepción: 07-02-2019

Fecha de aceptación: 26-03-2019

\section{RESUMEN}

De entre todos los objetos, tiempos, espacios, palabras y seres que componen el mundo físico, algunos están investidos de un valor especial por cuanto se les atribuye la virtud de visibilizar las instancias invisibles de las que dependemos los mortales. Es lo sagrado. A lo sagrado se le depara un trato singular hecho de respeto, veneración o miedo, pero en ocasiones también de rencor y de odio por lo que encarna o representa. Es adorado, pero también, y acaso por las mismas razones, puede ser insultado, destruido, objeto de burla y, si tiene forma humana, martirizado o asesinado. La violencia contra lo sagrado puede caber en sistemas religiosos que le otorgan a la agresión un papel central en su universo mítico o ritual. También se ofende u agrede lo santo para grupos o pueblos a someter, puesto que en ello está resumido su orden del mundo. Desde esta perspectiva, el agravio, la irreverencia y el daño pasan a reclamar un lugar protagonista en los estudios sobre la institución religiosa de la cultura bajo las figuras del sacrilegio y la profanación.

PALABRAS CLAVE: sagrado, profanación, sacrilegio, violencia religiosa, iconoclastia.

\section{ABSTRACT}

Of all the objects, times, spaces, words and beings that make up the physical world, some are invested with a special value because they are attributed the virtue of making visible the invisible instances on which we mortals depend. This is the sacred. The sacred is given a singular treatment combining respect, veneration or fear, but sometimes also resentment and hatred of what it embodies or represents. It is adored, but also, and perhaps for the same reasons, it can be insulted, destroyed, mocked and, if it has a human form, martyred or killed. Violence against the sacred can 
fit into religious systems that give aggression a central role in their mythical or ritual universe. Also offended or attacked is what is sacred for groups or peoples to be subdued, since in it an embodiment of their world order. From this perspective, aggravation, irreverence and damage occupy a central place in the studies on the religious institution of culture under the figures of sacrilege and profanation.

KEY WORDS: sacred, profanation, sacrilege, religious violence, iconoclasm.

\section{INTRODUCCIÓN}

Es de la mano de su ensayo sobre la naturaleza y la función del sacrificio que Henri Hubert y Marcel Mauss (2010 [1899]) plantearon la dicotomía sagrado/profano como recurso analítico estructural mediante el cual dar cuenta de la existencia de dos esferas incompatibles y excluyentes, pero en constante comunicación de ida y vuelta a través del ritual: una, la de lo profano, que agrupaba a las cosas corrientes y cotidianas, sin valor, y otra, la de lo sagrado, compuesta por cuerpos, sitios, momentos u objetos que las divinidades empleaban para hacerse presentes ante los humanos y que no eran accesibles sino mediante todo tipo de cuidados y prevenciones, dada su naturaleza completamente excepcional. De ahí tomó Émile Durkheim (2010 [1912]) la noción de sagrado para nombrar los lugares y momentos extraordinarios, radicamente aislados del resto, en que se producía la materialización de una trascendencia sobrenatural o ultramundana, mediante la cual actuaba el interés de las instituciones sociales en obtener obediencia y conformidad $^{1}$.

El valor universal y omniexplicativo atribuido a la dualidad sagrado/profano por la escuela de l'Année Sociologique ha sido matizado (Prades, 1998; Giobellina, 2014), pero no se ha encontrado ninguna otra convención terminológica para referirnos a la concreción sensible de aquellos axiomas que, impuestos a priori a la experiencia individual, constituyen los marcos permanentes de la vida mental de buen número de sociedades, aquellos que generan y distribuyen los significados socialmente institucionalizados mediante los cuales el desorden y la incertidumbre son mantenidos a raya. Es a través de lo sagrado -allí donde se da como categoría fundamental de la sensibilidad religiosa- que los humanos pueden establecer contacto con las instancias de las que sienten determinados de manera absoluta y que dictan los principios básicos que estructuran la vida tanto individual como colectiva, nexo que mantiene unidos y al tiempo separados a los vivos de entidades inmortales, tales como dioses, ángeles, demonios, espectros o ancestros, que personifican la autoridad de lo social o sus enemigos.

A través de las cosas sacramentadas, estas realidades inaprensibles pueden interpelar o ser interpeladas por quienes las imaginan. Es ese diálogo entre mundos, que es el qué ritual facilita, lo que le permite a los humanos expresar obediencia y sumisión a las

1 Lo sagrado tiene otro sentido para la fenomenología de la religión, para la que constituye una categoría explicativa y valorativa para indicar la emergencia de verdades inefables ajenas al mundo y a la razón, de las que emana un orden del cosmos del que son no sólo hipóstasis sino también puerta de acceso. Así, para Rudolf Otto (1980 [1917]), lo santo sería aquello que colocaría al ser humano ante lo numinoso, lo oculto y sublime, que no puede ser descrito ni definido, puesto que corresponde a una revelación externa de lo divino. En esa misma senda, Mircea Eliade (1981 [1957]) establece lo sagrado como hierofanía, esto es como emergencia en nuestro entorno cotidiano de una realidad totalmente diferente, que permite una toma de conciencia de la insondabilidad del misterio al tiempo que de su omnipresencia. Aquí, la noción de sagrado se mantiene fiel al paradigma teórico formulado por la primera sociología de la religión de Mauss y Durkheim. 
instancias invisibles, hacerles llegar ofrendas y súplicas, mereciendo de ellas, a cambio, bendiciones, gracias, perdón o misericordia. Ahora bien, también lo sagrado puede recibir evidencias de que las realidades trascendentes que a través suyo se manifiestan existen gracias a la lealtad humana y que los mortales pueden hacerles objeto de engaño, venganza, odio y, por supuesto, de todo tipo de ataques por parte de sus propios fieles. Por otro lado, lo sagrado también puede ser violado en tanto que es expresión palpable que los esquemas de los que emanan los recursos morales de una sociedad o un segmento social al que sojuzgar, desarbolando así su sistema de valores y dejándolos indefensos y desorientados ante procesos de desestructuración que se les imponen. Desde esta perspectiva, el agravio, la irreverencia o incluso la violencia contra lo sacro pasan a reclamar un lugar protagonista en los estudios sobre la institución religiosa de la cultura, bajo las figuras del sacrilegio, como ofensa a lo santo, y la profanación, en el sentido de desacralización hostil. Es en relación con esto que las páginas que siguen proponen una reflexión y, como consecuencia de ella, un tipología de modalidades de agresión que, en tanto ofenden a las cosas santificadas, son, ellas mismas y de algún modo, santas.

\section{TRANSGRESIONES SAGRADAS}

Sabemos que la violencia está presente en muchas modalidades de culto religioso como consecuencia de que el contacto entre ámbitos de realidad incompatibles -tan imperceptible como poderoso una de ellos- que lo sagrado permite es a menudo representado como traumático. Ocurre cuando el elemento conductor entre mundos es un individuo al que tal función confiere naturaleza sagrada, como en el caso de la posesión, el éxtasis místico, el trance chamánico o numerosas variantes de iniciación o rito de paso, que sueIen implicar espasmos, convulsiones, catalepsia y otras alteraciones somáticas en quienes los experimentan. Más todavía en el caso de los sacrificios cruentos, en los que el ser vivo en que se concentra la conexión sagrado-profano debe morir. En todos esos casos se demuestra hasta qué punto establecer comunicación con los superiores invisibles pasa con frecuencia por infringir al cuerpo propio o a otro ajeno algún tipo de daño simulado o real. Las modalidades de occisión en que el dios no es el destinatario sino el objeto mismo del dolor infringido por sus veneradores, no son una excepción. El cristianismo, como religión basada en el asesinato de la propia divinidad por el pueblo que le rinde culto, sería el mejor ejemplo de ello.

Por otra parte, el estudio comparado de los sistemas religiosos advierte de cómo estos pueden albergar en su seno un lugar para la violencia contra esa otra dimensión que lo sagrado trae. En no pocas sociedades, una vez han sido presentadas a la instancia sobrenatural las ofrendas pertinentes, se está en condiciones de exigirle la correspondiente contraprestación en forma de favores, ventajas o protección, lo que convierte todo presente a los dioses en una forma de soborno. Si estos defraudan las expectativas que en ellos se ha depositado, pueden ver interrumpido el suministro de signos de acatamiento o, incluso, resultar destinatarios de ataques. Ruth Benedict (1938: 640) ofrecía varios ejemplos de todo ello: en China, la representación del dios de la lluvia era destrozada en la misma procesión en la que se la implorabla si esta no obtenía resultado; los kai de Nueva Guinea o los tsimshian canadienses, insultaban y amenazaban al cielo a la mínima contrariedad; los manu de las Islas Bismarck no dudaban en expulsar airadamente a las potestades invocadas en caso de verse desencantados por su comportamiento. Esa especie de trato injurioso y al tiempo familiar con lo sagrado es el que ejemplifica en nuestro contexto cultural la blasfemia, una práctica lingüística consistente en llenar de heces o procacidades a Dios, Cristo, la Virgen, los santos, el cáliz o la hostia y que entronca con el realismo grosero al que se refiere Bajtin (1988 [1965]: 21-23), descenso a lo sórdido y lo sucio en que consiste la materialización radical de lo sagrado propio de las escenificaciones carnavalescas. 
No se trata de discutir las teorías que han supuesto el fondo u origen violento de la religión en sí y por tanto la naturaleza intrínsecamente violenta de lo sagrado, como ha sostenido René Girard (1983). Pero es cierto que la violencia ejercida contra aquello mismo a lo que una sociedad reverencía puede ser coherente con el hecho de que los mitos y ritos en que se funda estén, ellos mismos, cargados de episodios atroces, como es el caso del mensaje bíblico o, en el catolicismo, el de expresiones artísticas truculentas y con un universo festivo popular saturado de brutalidad (Mitchell, 1988). En todos los casos, la crueldad ejercida contra las cosas benditas no es la negación de su santidad, sino su requisito santificador. Se trata de contrarrituales o ritos de inversión en los que lo sagrado es objeto de transgresión, o, mejor dicho, en los que es la transgresión misma lo que se sacraliza, a la manera como teorizaran Roger Caillois (2014 [1939]) y luego Georges Bataille (2007 [1957]). En el caso católico, esto sucede con el visto bueno, si no con el patrocinio, de las mismas autoridades religiosas y en oportunidades marcadas en el calendario litúrgico, como el carnaval, las fiestas de locos o multitud de celebraciones populares.

Así pues, el sacrilegio y la profanación pueden caber dentro del mismo sistema cultual injuriado, como si de alguna forma los seres eternos estuvieran dispuestos a otorgar a los humanos la opción de una cierta reciprocidad ante las afrentas y los fracasos de los que se les considere responsables, devolviéndoles algo de la violencia que de ellos recibían. Se trataría de atribuir a la agresión un papel en el conjunto de mensajes que los fieles dirigen a sus propios dioses a través del daño relativo, la insolencia o el sarcasmo contra aquello que los visibiliza, como una reparación mínima concedida a los mortales, que no afecta estratégicamente a las relaciones de estos con lo consagrado, sino al contrario, las reafirma.

\section{LO SAGRADO: METÁFORA Y SACRAMENTO}

Hemos visto cómo una comunidad puede hacer objeto de burla, trato irreverente o incluso herir a las cosas sagradas, que pueden dejar de ser intocables en cuanto son merecedoras de reproches o venganza o cuando el propio sistema religioso prevé oportunidades para expresar insolencia $u$ hostilidad hacia ellas. Pero las exteriorizaciones de sacralidad que no podrán dejar de ser ofendidas serán las de aquellos a quienes se debe vencer. Acaso todas las guerras son, de un modo u otro, guerras de religión, en el sentido de que lo que justifica la superioridad moral que se autoarroga cada bando convierte su causa en sagrada $\mathrm{y}$, por tanto, en igualmente sagrada la violencia que ejerce contra el contrario. Del mismo modo, el rival suele tener entre sus atributos negativos una religiosidad deforme, perversa e inaceptable, en la que suele plasmarse la razón del aborrecimiento que merece. De hecho, la ofensa que la piedad de los antagonistas hace sufrir a la Verdad es la coartada que justifica la urgencia de derrotarlos, ya sea para redimirlos de su error, para expulsarlos, para subyugar o, si fuera preciso, para exterminarlos, como hemos conocido en el caso de las grandes persecuciones religiosas. En este caso, se plantea como urgente la destrucción de los lugares, objetos y servidores del culto de los adversarios, cualesquiera que estos sean y al margen de las razones de la hostilidad que provocan, puesto que es herir aquello que estos consideran sagrado lo que más les puede doler. Como si, de algún modo, la inquina contra cualquier enemigo tuviera que cumplir el decreto bíblico: "Suprimiréis todos los lugares donde los pueblos que vaís a desalojar han dado culto a sus dioses...; demoleréis sus altares, romperéis sus estelas, romperéis sus cipos, derribaréis las esculturas de sus dioses y suprimiréis su nombre de ese lugar" (Dt 12 23).

Los ejemplos históricos de violencia contra lo sagrado de aquellos que han sido declarados enemigos interiores o exteriores son abundantes. En el mundo antiguo encontramos la destrucción por Akhenaton de las estatuas de Amón o por Thumtosis III de las de la reina Hatshepsut en Egipto; la mutilación de estatuas de Hermes o de Hiparco en la Grecia clá- 
sica, o la promulgación de las reglas de Solón prohibiendo la ornamentación de las tumbas en el siglo VI a. C. ... Saltando a las últimas décadas, pensemos en los templos hindús, sijs o musulmanes que fueron atacados en la India en las diferentes oleadas de violencia sectaria que asolaron el país a principios de la década de los 90, el más destructivo el que afectó una mezquita en Uttar Pradesh, en 1992, que desembocó en enfrentamientos entre hindús y musulmanes en los que más de dos mil personas perecieron. En aquel mismo período, durante las guerras balcánicas de la década de 1990, los lugares de culto ortodoxos, católicos y musulmanes de Croacia o Bosnia fueron atacados por parte de unos u otros, ampliando aquella obsesión de los seguidores de Pavelic contra las iglesias cristianoorientales serbias en los años treinta. A lo largo de la década de 2010, los salafistas radicales ocasionaron matanzas al atentar contra mezquitas chiitas, sufís, pero también sunitas, en Iraq, Nigeria, Egipto, Siria, Filipinas.... Los ataques contra sinagogas en todo el mundo gotean año tras año, sean en nombre del antisionismo o actualizando el viejo odio antisemita. La expansión de las sectas evangélicas en todo el mundo ha traído consigo actos de violencia dirigidos a instituciones religiosas de las sociedades a colonizar espiritualmente, pero los protestantes tuvieron que padecer la destrucción de sus templos en la provincia de Aceh, en Indonesia, por musulmanes, en 2015. Los rohingyas vieron arder sus mezquitas durante el genocidio de que fueron objeto por el gobierno de Myanmar a partir de 2015. La lista de ejemplos podría ser mucho más amplia y alcanzar hasta ahora mismo.

Esta es, en última instancia, la razón que ha venido abonando la práctica metódica de la violencia contra todo aquello que pudiera remitir al estrato último, fundante y fundamental, para los pueblos o colectivos a someter. El objetivo de los actos sacrofílicos es, precisamente, el de desarticular el entramado mítico, ritual y simbólico del que depende la perpetuación de los esquemas que sostienen un determinado orden del mundo, cualquiera que este sea, donde y cuando sea. Arrasar templos; derribar imágenes; vejar a los dioses ajenos; destruir bibliotecas, códices o archivos; asesinar mediadores con lo eterno, es, allá donde se produzca, el medio más eficaz de arrancar de cuajo las raíces que hunden la vida social en el suelo de su propio pasado, hacer añicos sus fuentes de coherencia, hacerla víctima de una suerte de lobotomización que la desorienta por completo, la deja en blanco, la pone a merced de los cambios radicales que se avecinan de la mano de los destructores y del sistema de mundo que pretenden imponer por la fuerza.

Pero no todas las formas de violencia contra lo sagrado de y para los otros tiene idénticas motivaciones y fines. Es importante resaltar, como propone Bruno Latour (2002), que existen diferentes modalidades de agresión a lo santo, distinguibles en función de la motivación de los atacantes y el papel que le conceden a las cosas dañadas, así como de la relación que mantienen con sus cosas sagradas las víctimas de esa violencia que se ensaña con ellas. Hemos visto cómo la violencia puede ejercerse en el marco del sistema religioso de una sociedad, que le puede otorgar a esa violencia de los propios fieles una eficacia en sí misma santificante. Cuando se aplica contra adversarios, la violencia contra lo sagrado puede desplegarse en nombre de argumentos que pueden ser teológicos o resultar de ideologías laícas, en la medida que la naturaleza de lo santificado sea reconocida como la de una encarnación o la de una representación de lo sobrehumano.

En el primer caso, el de las cosas sagradas como encarnaciones, estas se constituyen en sacramentos, por emplear la distinción de Bateson en su epistemología de lo sagrado (Bateson y Bateson, 1989: 29-64), en los que se produce un efecto de presencia (Gumbrecht, 2005: 12-14), en tanto comunican lo incomunicable de manera inmediata, sin mediar interpretación. En términos semiológicos, la cosa adoradada se coloca en el plano sintagmático y metonímico, puesto que lo material no sustituye a lo inmaterial, sino que lo realiza. En el segundo caso, lo sagrado no pretende ser una entidad sobrehumana, sino sólo evo- 
carla, puesto que se limita a ocupar su lugar, como corresponde a las figuras retóricas de la metáfora o la sinécdoque o al plano paradigmático del lenguaje. Cuando lo sagrado como encarnación es censurado lo es en tanto que idolatría; si lo es en tanto que representación, su descalificación le asigna el defecto de fetichismo. La persecución de las cosas sagradas veneradas como ídolos acusa a estas no de evocar una entidad misteriosa, sino de su empeño en serlo. A diferencia de la dirigida contra ídolos, la violencia contra el objeto sagrado como fetiche responde a su consideración como carente de todo poder, puesto que es sólo una mera forma material vacía a la que se dedica un culto supersticioso.

El combate contra la idolatría presupone que lo sagrado de los contrarios no es un signo divino sino el soporte físico de dioses impostores o potencias diabólicas, que engañan a los mortales haciéndose pasar por celestiales. La agresión se dirige a esa potencia abyecta que se ha corporeizado y actúa a través de lo sagrado, es decir al contrario de jainistas o budistas mahayana en Oriente (Rambelli y Reinders, 2012), que si rechazaron el culto a lo concreto no fue por la imposibilidad de percibir lo sobrenatural en el mundo, sino por su empeño panteísta en encontrarlo por doquier. La idolatría es acusada de convertir el objeto sagrado en sujeto, puesto que lo supone de algún modo poseído. En buena medida podríamos decir que la acusación de idolatría implica que los adoradores están percibiendo lo sagrado no como objeto, sino como sujeto, puesto que lo viven como poseído por seres no humanos de naturaleza pérfida.

Por su lado, la acusación de la cosa venerada como expresión de fetichismo se corresponde con la inclinación religiosa que la crítica ilustrada denunciara como prueba de la ignorancia de las clases bajas o la superstición de otros pueblos, puesto que supone, siguiendo la definición de De Brosses, un culto directo, inmediatamente rendido a objetos, plantas o animales, una creencia estúpida, infantil que indica un escalón evolutivo inferior. Los ataques contra objetos, lugares y personas asociados a un determinado culto condenado como fetichista acompañaron el proceso de secularización en los Estados modernos, como parte de la desarticulación de los restos del Antiguo Régimen, y de la expansión colonial europea en los siglos XIX y XX, en nombre de la elevación cultural de los pueblos invadidos.

Esa tipificación para distinguir las formas de violencia contra expresiones religiosas como idolátricas o fetichistas ha sido importante para marcar etapas de la persecución contra lo sagrado de los pueblos originarios en la conquista de América (Bernard y Gruzinski, 1993), pero también serviría para explicar el desarrollo de su deposición en las sociedades africanas (Goody, 2003; Sarró, 2009). La devastación que vienen padeciendo los sistemas de representación tradicionales en África, como resultado de la presencia del cristianismo y el Islam ha comportado destrucción de máscaras, estatuas, amuletos, planchas..., y la prohibición de todo tipo de rituales, todo ello interpretado como signo de paganía. En cambio, la colonización de aquel continente, desprendida de toda coartada salvadora y fundada solo en argumentos civilizatorios, ha ejercido una forma de violación de lo sagrado bien conocido en otras culturas dominadas por Occidente: el secuestro, es decir el robo. Despojadas de su condición de vehículos de comunicación con lo transmundano y consideradas sólo en función de su valor museístico, han sido profanadas en el sentido literal anotado por Agamben (2005: 95), esto es como pérdida de su "indisponibilidad especial" como reservadas a los dioses, por mucho que sea a manos de científicos y en nombre de saberes. Véase, por ejemplo, cómo una de las tareas principales de la misión etnográfica francesa Dakar-Yibuti, a principios de los años 30 (Leiris, 2007 [1933]), fue el pillaje sistemático de objetos sagrados en los lugares por los que iba pasando. 


\section{LO SAGRADO, POSEÍDO}

La lucha de las religiones monoteístas contra lo que interpretaban como expresiones internas o externas de idolatría ha sido una constante allí donde han pretendido imponerse. Un ejemplo de ello sería el colosal experimento de implantación de un sistema de representación figurativa, el cristiano-católico, sobre la base de la reorientación de otro preexistente, el amerindio (Gruzinski, 2014). Ese conflicto estuvo todo él hecho de negociaciones, apropiaciones, reinterpretaciones..., que actuaron en un sentido muchas veces contradictorio. Como se sabe, los colonizadores impusieron las imágenes o lugares de culto católicos sobre los de los nativos, pero también se conoció enseguida la astucia de las figuraciones indígenas en orden a encontrar acomodo en el nuevo orden simbólico que los españoles trajeron consigo. En ese contexto, la destrucción de cosas sagradas -las huacas indígenas- se hizo en nombre de su consideración de epifanía de dioses impostores o demonios, pero no implicaba una impugnación global de su capacidad de ser epifanía de instancias sobrehumanas, sino voluntad de desalojarlas del espacio sagrado que habían usurpado. La pugna era entre dos imaginarios sagrados -el de los colonizadores y el de los colonizadoscuya eficiencia se demostró enseguida de desigual calibre, pero en la que no se cuestionaban la potencia que ciertos objetos del mundo sensible eran susceptibles de desplegar.

Esa lógica no fue la que impulsó en aquel mismo momento de la Edad Moderna el combate de la Reforma contra la Iglesia católica, ella misma considerada rehén de aquella idolatría que estaba combatiendo en América. En el caso de las guerras de religión en Europa, lo que impugnaban los seguidores de Calvino o Zuinglio era la pretensión de cualquier objeto material de desbordar el campo de la representación y devenir eficaz en el plano de la realidad. Esa era la naturaleza que la consideración que los católicos daban a sus objetos de culto desde el Concilio de Nicea, en el siglo VIII, en un dogma revalidadado luego en de Trento, en el XVI: Dios, los santos o la Virgen no eran "adorados", sino "venerados" a través de sus imágenes, puesto que se reconocía la presencia real y concreta de lo representado en su representación. Lo santo no sólo vive por sus imágenes sino también en ellas, puesto que no ocupan su lugar a la manera de un sucedáneo o imitación, sino que son su literalidad (Auzépy, 1987). La imagen recibe una valoración sustitutiva y sustantivizadora que no es sino la consecuencia de la extensión al conjunto de los objetos de culto del principio de la transustanciación de la Hostia en la Eucaristía, proclamado por la Iglesia en el 1215, que las masas cristianas ya habían ampliado por su cuenta, a lo largo de toda la Alta Edad Media, al conjunto de imágenes y reliquias, acaso como herencia del culto a la efigie y las reliquias del Emperador en la Antigua Roma.

Que los católicos rindieran culto a objetos percibidos como de algún modo poseídos era, para los reformistas, prueba de su idolatría, puesto que constituía una sobrevaloración blasfema de la materia como vehículo de comunicación con lo divino, que ocultaba, disimulaba y, lo que es peor, confiscaba la presencia de Dios y la sustituía por la del Diablo, puesto que el poder taumatúrgico atribuido a lo que se tenía por sagrado era de esencia maligna. Estamos, en este caso, ante un episodio de la llamada querella de las imágenes, una lucha que ya llevaba siglos en marcha por liberar las costumbres religiosas de lo que era considerado un exceso de dependencia con respecto de los símbolos externos. La justificación de los ataques reposaba en fuentes bíblicas y acusaba a sus destinatarios de haber traicionado la prohibición mosaica de representar lo divino: "No te harás escultura ni imagen alguna, ni de lo que hay arriba en los cielos, ni de lo que hay abajo en la tierra, ni de lo que hay en las aguas debajo de la tierra. No te postrarás ante ellas, ni les darás culto" (Dt. 6 89).

La historia de la iconoclastia cristiana había arrancado con las grandes revueltas antiidolátricas del Bizancio entre el 726 y el 787 y entre el 815 y el 843 (Grabar, 1998). La censura de la posibilidad de circunscribir físicamente lo inefable de la divinidad había sido plan- 
teada antes por el Concilio de Elvira en el 300, por padres como Eusebio de Cesárea o por sectas como los monofisitas, de igual modo que fue incorporado por la revolución islámica del siglo VII, pero no se había traducido forzosamente en persecución contra la sacralización de imágenes. En cambio, las grandes oleadas de violencia iconoclasta que emprenden León el Isáurico y León $V$ el Armenio traducen la impugnación dogmática en violencia, pero una violencia que no implicaba profanación. Al contrario, y como lo sería posteriormente, era la objetuación de lo sagrado lo que ofendía, puesto que es la pretensión de que lo divino puede interpelar o ser interpelado a través de mediaciones materiales lo que constituye sacrilegio (Beçanson, 2003; Freedberg, 2017). La violencia contra las imágenes vengaba un ultraje cometido contra la necesaria invisibilidad de lo sagrado.

El ejercicio de formas de ira sagrada contra cualquier expresión extrínseca de culto a objetos tangibles como indicativa de paganía, continuaría en adelante en los movimientos proféticos de la Baja Edad Media europea, que expresaron la urgencia de acabar con la sacralización de la materia: pastoreaux o seguidores de Arnaldo de Brescia en el XII; dulcinianos a finales del XIII; lolardos en el siglo XIV; taboritas, seguidores de Savonarola o de Pedro Bernardino en el siglo XV; campesinos anabaptistas de la primera mitad del $\mathrm{XVI}$... En todos estos movimientos, la violencia contra las imágenes sagradas expresaba la denuncia de lo que era considerado un exceso pervertidor de la autenticidad religiosa, que ya anunciaba lo que sería el rechazo racionalista del lenguaje alegórico y las modalidades analógicas de conocimiento. En la clave religiosa en que se argumentaba, la eliminación de la corruptora veneración a las imágenes era requisito para la restauración de la Ley Divina, puesto que el rechazo a la cosificación de lo sagrado derivaba de una percepción en ella de la presencia de lo demoníaco, señal del reino de opresión que un mandato divino ordenaba abolir.

Estas agitaciones heréticas precedieron las revoluciones puritanas de los siglos XVI y XVII, todas con un fuerte componente iconoclasta: Inglaterra (Phillipps, 1973; Aston, 1988; Hill, 2015), Países Bajos (Creew, 1978) o Francia (Garrisson Estebe, 1975; Crouzet, 1990; Davis, 1993). En todos los casos, la violencia contra las imposturas diabólicas disfrazadas de sacralidad ya no buscaba sustituir unas modalidades externas de comunicación con lo infinito por otras, como estaba haciendo la expansión española en América, sino que su objetivo era acabar con la posibilidad misma de establecerlas por medio de símbolos palpables, contemplados como el reverso oscuro de la verdadera latria, la debida sólo a Dios, su inversión satánica, tal y como aparecía recogido tanto en el Viejo Testamento -"Sacrifican a los demonios, no a Dios" (Dt. 32 17)-, como en el Nuevo -"Pero lo que inmolan los gentiles, ¡lo inmolan a los demonios, no a Dios!"- (1 Co. 10 20). Se asumían con ello las tesis antiidolátricas de von Karlstadt: Dios es espíritu; por tanto, sólo puede ser adorado espiritualmente (Cottret, 1984). El único medio para acceder a una pálida intuición de la sobrenaturalidad pasa a ser entonces la experiencia privada, la conciencia personal sacramentada, interlocutora exclusiva del Espíritu y vía única de distribución de su Gracia.

Las revoluciones puritanas del siglo XVI fueron mucho más lejos en sus planteamientos contra el status de la imagen sagrada que los del aconicismo musulmán, por mucho que compartiera con este y con el judaísmo una confianza absoluta en la Palabra revelada y escrita. Ahora bien, el rigorismo antiidolátrico de los calvinistas tuvo su replica en el wahabismo, una corriente del Islam surgida en el siglo XVIII a partir de la doctrina de Ibn Abd il-Wahhab. Si hasta entonces, y como veremos, el Islam había permitido sobrevivir el culto a las imágenes en los territorios sometidos, su variante wahabita implicó una intolerancia sin fisuras contra los símbolos externos en que se basaba la devoción popular en las zonas bajo su control, todo ese universo ritual que la ambigüedad coránica ante las imágenes había permitido sobrevivir. Prohibió los minaretes de las mezquitas, así como el culto a 
los santos y a los ángeles y ha impelido décadas de demolición de tumbas, santuarios y mezquitas en Arabia Saudí hasta la actualidad. El auge de derivados del wahabismo como el deobandismo o el salafismo - de Al Qaeda al Dáesh- estuvo en la base, al principio del siglo XXI, de la devastación de lo que se percibían como testimonios de idolatría a arrancar de cuajo, como los Budas gigantes de Bamiyán, en Afganistán, en 2001; la mezquita milenaria de Tombuctú, en Mali, en 2012, o los restos de los templos de Baal y Baalshamin en Palmira, además de gran número de mausoleos, iglesias, monasterios, mezquitas y restos artísticos y arqueológicos en Siria e Iraq (Beránek y Ťupek, 2018).

\section{VIOLENCIA Y DESFANATIZACIÓN}

Compartiendo la premisa de que cualquier externalidad es incompatible con una experiencia real de lo sagrado, posible sólo por medio de la fe interior, la consideración de los objetos sacralizados como fetiches es distinta de la que los reconocía como portadores de una presencia sobrenatural, pero negativa, es decir como ídolos. Ahora, en la adoración a cosas físicas se reconoce la inferioridad de pueblos o sectores sociales que satisfacen sus necesidades espirituales con meros sucedáneos intrascendentes. En este caso, el desprecio hacia los objetos sagrados, considerados como falsificación o fraude, resulta de su estatuto de expresión de fanatismo, tal y como lo definía Voltaire en L'Encyclopédie, es decir como "un fervor ciego y apasionado brotado de la superstición, que causa acciones ridículas, injustas y crueles [...] El fanatismo, por consiguiente, es la superstición en acción" (Blom, 2007: 281).

El precedente principal de esa descalificación de la sacralización de cosas materiales en tanto que vacías está presente en la actitud del Islam al respecto. Su incidencia sobre la sacramentalización figurativa no se traducirá necesariamente en destrucción y se limitará a las restricciones impuestas sobre el culto a iconos de bulto exento entre los cristianos sometidos, lo que permitió que los prolongados períodos de dominación árabe u otomana no afectaran la integridad de los iconostasios de las iglesias cristianas arábigas y eurorientales. Es cierto que Mahoma luchó contra la idolatría árabe preislámica, pero los musulmanes nunca llegaron a renunciar a algunos de sus elementos, como lo demuestra el lugar protagonista que continuó reservándose a la kaaba, pero sobre todo el uso de rosarios o amuletos, el culto a los santones, los ángeles o las tumbas, especialmente intenso en el sufismo. La clave de la actitud más tolerante del Islam respecto de la iconofilia hay que buscarla en el status de inocuidad que el Corán supone a las formas naturalistas de culto: "Los idólatras han tomado otros dioses distintos de Él, dioses que no han creado nada, que han sido creados. Que no pueden hacer ningún bien ni ningún mal, que no disponen de la vida, ni de la muerte, ni de la resurrección" (25 3-4).

Esa valoración de las cosas sagradas como merecedoras de ser despreciadas más que destruídas, fue la que hizo suya Lutero (1948: 80), para quien las imágenes tenidas por sagradas eran neutras, es decir adiáforas, consecuencia de que, como señala en su Gran Catecismo, "los paganos adoraban en sus falsos dioses creaciones de su imaginación y de sus fantasías y confiaban en la pura nada" (Luther, 2012 [1529]: 80). Esta percepción de las figuraciones religiosas como desprovistas de toda eficacia, formalizada por Philipp Melanchton y compartida por los anglicanos lauditas, fue la que encontramos en la base de las primeras teorías sobre el fetichismo (Sansi, 2009) y en la postura no demasiado beligerante contra objetos y formas rituales que la Revolución de 1789 acabaría imitando para sus propias simbolizaciones. Así, en el periodo revolucionario, la destrucción de elementos religiosos no fue constante ni generalizada (Hermant, 1978; Gamboni, 2014), entre otras cosas porque el nuevo régimen no asumió como doctrina el ateísmo y sus dirigentes tendieron a considerar la antirreligiosidad como aristocrática, al tiempo que ensalzaban un ritualismo vagamente teísta. 
Fue el anticlericalismo ideológico ilustrado -Holbach, Volney, Voltaire- el que encontraría su continuidad en el librepensamiento burgués decimonónico. Este será, variable en cuanto a intensidad, uno de los asuntos que centró, en Europa y América, el proceso de modernización a lo largo del siglo XIX, con sus implicaciones en forma de disputas contra el monopolio educativo de la Iglesia, leyes de divorcio, laicización de los cementerios, expulsión de los jesuitas, amortización de bienes eclesiales, exclaustraciones en masa... En todos los casos, estas dinámicas no se producen por fuerza en clave antirreligiosa y son compatibles con las formas de piedad, como las reformadas, que no cuestionan el acuartelamiento de lo sagrado en la experiencia personal, ese principio que, como veremos, convertirá al individuo bendecido por la Gracia en el único objeto místico, digno de consideración ritual, en un tiempo y un espacio sobre el que Dios actúa, pero en los que no está.

En efecto, los procesos históricos modernizadores definidos desde el liberalismo y asumidos por los movimientos de masas revolucionarios, con un fuerte contenido secularizante y anticlerical, impugnan la naturaleza supersticiosa de las cosas tenidas por sagradas, pero ello no comporta que estas deban ser deshonradas o dañadas. En cuanto al movimento obrero, en el siglo XIX, el control que sobre él ejercieron los socialistas, con su desconfianza hacia un anticlericalismo que asociaban con el reformismo burgués (Mellor, 1967; Arbeola, 1973), determinó un contenido iconofílico bajo y las agresiones anticatólicas tuvieron un papel residual, incluso en el marco de grandes explosiones insurreccionales como la Comuna de 1871 (Lalouette, 1997). Por citar otro ejemplo europeo, Italia vivió a lo largo del siglo XIX un proceso histórico con un fuerte componente liberal y radical-populista, con una "cuestión romana" central para sus propósitos de unificación política y modernización económico-social. Pero no se cuestiona darle al proyecto italiano un primado ético-civil tomado del catolicismo como base para la vida nacional. A pesar del radicalismo garibaldino, no se localizan en Italia estallidos destacables de violencia contra los cultos externos hasta la Settimana Rossa de junio de 1914 (Mannelli, 2002), que tampoco fue generalizada y no puede compararse, por ejemplo, con la que se conoció Barcelona en la Semana Trágica, el verano de 1909 (Ullman, 2009 [1968]).

Que reformismo liberal implicó consustancialmente anticlericalismo, esto es desactivación del poder eclesial, pero no por fuerza vandalización, queda todavía más claro en el caso latinoamericano, con la excepción tardía de México. En el siglo XIX América Latina conoció movimientos de independencia influenciados por los ideales jacobinos y masones, pero, a pesar de que en todos los casos se registran dinámicas de secularización destinadas a restringir el papel de la religión en la vida civil, la presencia de agitaciones iconoclastas es escasa en los respectivos procesos de construcción nacional. Algunos nuevos Estados -como Perú o Venezuela- se autoproclamaron católicos y casi ninguno pretendió una laicización taxativa de la sociedad. Están bien estudiados casos como el colombiano (Arce Fustero, 2019) o el argentino (Di Stefano, 2010), que tuvo que esperar hasta 1955 para conocer brotes de furia anticlerical, como el incendio de la Curia, el asalto a la catedral y los ataques con cócteles molotov contra iglesias en Buenos Aires en junio, consecuencia del ambiente que había creado la derogación de la ley de enseñanza religiosa por Perón el año anterior y, sobre todo, la intentona militar del 11 de aquel mes.

El anticlericalismo fue un ingrediente del programa político del radicalismo republicano y, adoptado de él, del anarquismo, pero, como hemos visto, su presencia en la tradición socialista y luego comunista fue débil, por cuanto tendieron a considerarlo como una deformación ideológica liberal-burguesa y un elemento de distracción respecto del papel central atribuido a la lucha de clases. A pesar de ello, durante las primeras décadas de la Unión Soviética se demolieron una gran cantidad de monumentos religiosos y de iglesias, mezquitas y sinagogas. Miles de popes y sacerdotes católicos fueron fusilados entre 1918 y 1941, en 
diferentes campañas antirreligiosas (De Baets, 2014). En China, se destruyeron decenas de santuarios budistas durante la ocupación del Tibet y la Revolución Cultural (1966-1968) trajo consigo la misma suerte para multitud de templos budistas, cristianos y confucionistas (Reinders, 2004). En países como Rumanía y bajo la dictadura de Pol Pot en Camboya se desarrollaron ofensivas purificadoras parecidas. Pero, salvo casos como la destrucción de iglesias, mezquitas y tekkes sufís a cargo de turbas en Albania en 1967, la violencia contra la religión en los países comunistas no solió ser la consecuencia de actuaciones tumultuosas, sino de decisiones o consignas institucionales ejecutadas por empleados que cumplían órdenes o por destacamentos actuando con el consentimiento oficial.

De ese tipo de profanaciones gubernativas fueron las que acompañaron las políticas laicizantes en México. En aquel país, el proyecto de modernización tomará consciencia enseguida de la urgencia de desbaratar un entramado de sacramentalización de las viejas redes societarias, basado en gran medida en el prestigio concedido a las imágenes. La ley de separación Iglesia-Estado de 1859 y la Constitución de 1917 definían ya un plan de liquidación del poder eclesial, y es en su nombre que Carranza ordena la destrucción de objetos religiosos. Bajo el régimen radical-populista de Plutarco Elías Calles (1924-1928) se desarrollará una ofensiva anticlerical que provocará la revuelta cristera, en el marco de la cual las profanaciones violentas serán constantes. Los estados del Golfo y del sur que habían quedado al margen de la Cristiada conocen aun mayor intensidad en las prácticas desfanatizadoras, consistentes en fusilamiento de sacerdotes, destrucción de imágenes de santos y vírgenes o la demolición de templos enteros, entre ellos algunas catedrales como la de Tabasco. Luego, en 1931, en Jalpa, los camisas rojas incineraban más de dos mil "fetiches". Los actos iconoclastas fueron también frecuentes en Veracruz, Yucatán y en Chiapas, donde los intercambios de santos entre comunidades indias habían sido una de las prácticas tradicionales más extendidas. Allí, el gobernador callista Victórico Grajales despliega agentes dedicados a destruir todas las imágenes de santos que encontraran, quemándolas en público o decapitanto las de las fachadas de las iglesias. Son los quemasantos (Ríos Figueroa, 2002: 73-112). La expresión más rotunda de ese movimiento iconófobo la encarna el gobernador Tomás Garrido en Tabasco, que impone, desde 1928, un auténtico régimen de terror contra todo cuanto tuviera que ver con el culto católico (Martínez Assad, 1991).

El otro gran caso en que al proceso de modernización, y a su ingrediente anticlerical, se le añade una preocupación central por violentar las cosas santificadas es el español, que presenta características singulares y cuyas raíces culturales ya han sido apuntadas (Ranzato, 1998; Ledesma, 2005; Delgado, 2012; Thomas, 2014). A diferencia de la iconoclastia gubernamental que se produjo en México y bajo sistemas comunistas, en España, lo sagrado -lugares, momentos, personas, objetos...- sufrió ataques en diferentes momentos de los siglos XIX y XX, casi siempre a cargo de muchedumbres anónimas o de piquetes incontrolados $y$, además, no en periodos prolongados, sino en forma de estallidos no programados. En estas oportunidades, las imágenes sagradas fueron decapitadas, apedreadas, fusiladas, arrastradas por las calles, objeto de burlas procaces; ardieron en público altares, crucifijos, cálices, piezas de arte, archivos...; conventos, iglesias, locales parroquiales, grandes catedrales, pero también ermitas remotas, fueron incendiadas o convertidas en ruinas; un patrimonio artístico y cultural de extraordinario valor desapareció para siempre; cientos de servidores del culto fueron asesinados, con frecuencia linchados o empleando escenificaciones casi litúrgicas. Una exasperación extraordinaria se desató en cuadros históricos críticos, desacatando muchas veces su lógica o dislocándola por la vía de la exageración y el desquiciamiento. Eso ocurrió acompañando el conflicto antirregalista entre 1820 y 1823 , los reveses del ejército liberal en 1834 y 1835, los acontecimientos revolucionarios de 1854 o 1868, la revuelta cantonalista de 1873, la leva de tropas en 1909, la proclamación de la 
República en 1931, el levantamiento en Asturias en 1934 o la sublevación militar en 1936, este último resaltable por sus consecuencias en cuanto a muertes y estragos².

Podría interpretarse la intensidad destructiva del anticlericalismo popular en la España contemporánea como el resultado de la convergencia entre dos órdenes simbólicos. De un lado, el sustrato lo aportaría un caudal de creencias y prácticas populares en las que la fobia y la filia hacia lo sagrado mantenían entre una relación plástica y ambivalente, y un universo de expresiones festivas tradicionales basadas en la agresión a seres vivos o que representaban la vida, costumbres que ya eran modelos de y para la violencia pública. Por el otro, la urgencia por desbaratar un orden simbólico a través del qual se vehiculaba el ascendente de las comunidades locales, incompatible con el establecimiento de Estados modernos centralizados. Si el primer factor proporcionaba un imaginario y un repertorio ritual a imitar, el segundo proveía tanto de ocasiones históricas como de racionalizaciones ideológicas. Un elemento y otro confluyendo para desencadenar, como coincidencia a su vez de dinámicas amplias y de un contexto histórico histórico preciso, uno de los más destructivos estallidos de rabia colectiva contra lo sagrado registrado en la historia reciente, el verano de 1936.

\section{EL LAICISMO Y LA REUBICACIÓN DE LO SAGRADO}

Bien puede sostenerse que el proceso de secularización que acompañó la expansión modernizadora a nivel planetario ha ido desactivando en buena medida el viejo poder de las cosas sacramentadas como instrumentos de intercesión de los humanos ante lo incognoscible. Tanto en las sociedades urbano-industriales como en buen número de las que se encuentran en vías de serlo. El papel de lo sagrado -entendido siempre como presencia o representación de lo eterno- se restringe, hoy, al valor que le otorgan sus veneradores, pero ya no se imponen a toda la sociedad ni siquiera en casi todos los Estados confesionales. La iconoclastia ha quedado restringida al campo del arte y para nombrar ataques contra obras o la intención desmitificadora de ciertas corrientes de vanguardia (G. Romaro, 2002). Puede decirse que se ha cumplido en buena medida el pronóstico weberiano sobre el desencantamiento del mundo, al menos en tanto que desacralización. Es cierto que hay elementos que han ocupado el lugar de lo sagrado depuesto -sitios, objetos, personas-, solo que ahora no pretenden comunicar con lo infinito, sino ponerse al servicio de los nuevos cultos seculares, sustitutos de la religión, provistos por la política -el nacionalismo (Llobera, 1996) - o la economía -el propio capitalismo (Benjamin, 2014 [1921])-, pero también otros como la cultura, los espectáculos de masas o el sistema de consumo, que han engendrado nuevas formas de fetichismo o de idolatría y sus correspondencias fobias.

Recuérdese que el principio de laicidad no postulaba sólo una autonomía del poder político-jurídico con respecto a toda deriva religiosa, sino una aconfesionalidad activa del Estado (Otaola, 1999: 11), comprometido en garantizar el sostenimiento de un espacio cívico-político fundamentado en la defensa del ciudadano como sujeto político fundamental. Laicización es, por tanto, idéntico a proceso de descontaminación de la vida pública de todo lo concerniente a lo absoluto, cuya presencia no se concibe en otro espacio que no sea el del sagrario personal. Pero ello no implica que el laicismo se postulara como contrario ni

2 Cada una de estas excitaciones de violencia religiosa debe ser explicada teniendo en cuenta circunstancias políticas y ambientes sociales particulares, así como racionalizaciones cambiantes, siempre en un sentido de aplicación radical y expeditiva del proyecto de extirpación de lo sagrado de la vida pública. Para una atención pormenorizada y en clave diacrónica de este último aspecto, el de las diferentes expresiones del ideario laicista en el marco del proceso de modernización en España, véanse Callahan (1989 y 2003), Lannon (1990), La Parra López y Suárez Cortina (eds.) (1998) o Cueva Merino y Montero García (eds), (2007 y 2009). 
incompatible con la religión y la mayoría de denominaciones, al menos en las sociedades modernizadas, aceptan su canon fundamental, que es el de la separación entre sus competencias y las del Estado. En efecto, la pretensión inicial del laicismo como doctrina no fue atacar la religión, sino, al contrario, garantizar la libertad de conciencia y la pluralidad religiosa. La alternativa al fanatismo religioso no era la irreligiosidad, sino la tolerancia religiosa como movimiento emancipador que, ubicando al sujeto ciudadano en su centro, plantease el diálogo entre el conjunto heterogéneo de religiosidades y una sociedad moderna en proceso de secularización (Habermas et al., 2011). La laicidad se postuló como el modelo teórico para la convivencia en la esfera pública de una diversidad de agentes libres y autónomos, creyentes y no creyentes, formados en virtudes cívicas, que ejercen la soberanía última sobre sí mismos y sobre la gestión de los asuntos colectivos que les conciernen.

Todo ello implica que la laicización fue un proceso de introspección de lo sagrado en el sujeto y su subjetividad, que quedaban eximidos de la obediencia hasta entonces debida a cualquier vehículo externo de autoridad sobrenatural. Y es la preeminencia de lo subjetivo, basado en la inmanencia de los sentimientos íntimos y la búsqueda de una autenticidad personal, en lo que se cimentan los valores del sistema jurídico-filosófico propio de las sociedades modernizadas, que coloca al individuo psicofísico como fundamento y fin de todas las leyes y relaciones morales y políticas. La premisa de la individualización es la de que las personas cual debe dirigir su conducta al margen de los presupuestos morales heredados de la tradición y cuya obediencia la comunidad a la que pertenece vigilaría. Para que se diese ese proceso de subjetivación, del que dimanará la figura moderna del ciudadano, era indispensable que lo sagrado abandonase lo que había sido su carácter factible y objectivo, y actuase desde el corazón de cada cual. La dicotomía sagrado/profano pasaba a equivaler a la de privado/público, o mejor, intimo/público.

La renuncia de la religión a continuar ejerciendo todo dominio mediante extroversiones rituales dejaba en libertad a los individuos para elegir sus propias reglas morales, puesto que la vida social había dejado de tener un sentido único y obligatorio. Se rompía con la identificación comunidad-religión, ya que esta última aparecía restringida a producir estructuras de plausibilidad fragmentarias y con una eficacia que sólo podía funcionar a nivel individual 0 , como mucho, familiar o de comunidades restringidas y encapsuladas, pero nunca del conjunto de miembros de una sociedad cada vez más globalizada. De hecho, en Occidente, las nuevas religiosidades elitistas -cultos de inspiración oriental, conocimientos paranormales, neopaganismo y toda la nebulosa de corrientes new age- son todas ellas subjetivistas y arrogan la última palabra sobre el significado último de la revelación personal de lo sagrado. La expansión planetaria del pentescotalismo se ha fundamentado en su capacidad de suscitar una piedad que es al tiempo colectiva y personal. Incluso la Iglesia católica, mediante la aparición en su seno de tendencias carismáticas, se ha sumado a esa corriente que entiende que es la presencia del creyente, y no la institución, la que sacraliza el lugar en que se reúne con otros para orar. Por su parte, la expansión del Islam en buena parte del mundo, incluyendo poblaciones blancas en Europa y América, se ha producido de la mano de la fascinación que suscita su variable más vivencial, el sufismo. En todos los casos y por doquier, estamos viendo cómo lo sagrado, en su acepción de nexo que permite el diálogo con lo absoluto determinante, encuentra su último y legítimo refugio en la soledad de cada individuo, haciendo de él la cosa santa por excelencia, un templo viviente que debe estar en todo momento rodeado de prohibiciones y prevenciones rituales que garanticen el respeto que se le debe como única expresión visible de lo invisible.

He ahí algo que la primera sociología reconoció como uno de los rasgos de la vida moderna. Toda la teoría del secreto de Georg Simmel (1986 [1906]) se levanta sobre el señalamiento de esa esfera ideal que envuelve a cada individuo, una esfera que lo blinda y 
hace de él algo intocable, esto es sagrado, que es diferente para cada cual y del que violar Ios límites ponía en peligro o destruía la personalidad que alberga. Lo mismo Émile Durkheim (2006 [1906]: 37), para quien el alma de un ser humano es una porción de sacralidad, una especie de forma individualizada de mana. "La personalidad humana es cosa sagrada, que no se intenta violar y se la mantiene escrupulosamente dentro del ámbito de la persona". Estos fueron los presupuestos sobre los que asentó Erving Goffman (2009 [1959]) su teoría sobre las ritualizaciones que orientan toda interacción social, es decir cómo actuamos en presencia de los demás como si fueran pequeños dioses, la relación con los cuales debe estar sometida a todo tipo de liturgias, a veces microscópicas, mediante las cuales reconocemos lo inviolable de su integridad y el temor a las sanciones que nos esperan si la profanamos.

\section{CONCLUSIONES}

No en todas, pero sí en numerosas sociedades, existe una distinción entre dos categorías antagónicas e irreconciliables de cosas: de un lado las mundanas, ordinarias, rutinarias...; del otro, cosas completamente excepcionales, irrenunciables, la alteración de las cuales, su daño u ofensa y no digamos su destrucción, son experimentados por quienes las aprecian como un motivo de desorganización moral. Es lo intocable, aquello que debe ser aislado de todo contacto inconveniente, sustraído al intercambio, cuya manipulación está rodeada de todo tipo de cuidados o precauciones y cuya presencia o cercanía suscitan algo parecido a una reacción reverencial automática, que puede consistir en temor, exaltación, arrobo, postración y otros sentimientos excepcionales, incluso el desprecio y el odio. En cualquier caso, para las ciencias sociales de la religión, la santidad asignada a un determinado objeto resulta de la manera no solo como vehicula algo poderoso y vital, sino de su capacidad para incitar sentimientos y acciones, como si fuera lo que los psicólogos behavoristas llaman un refuerzo conductual, un estímulo que suscita una reacción predeterminada, en el extremo opuesto a la indiferencia.

A partir de ahí, lo que se ha querido poner de manifiesto en las páginas precedentes es que, por un lado, la violencia puede formar parte de un sistema de culto, como uno de sus ingredientes, como si la agresión contra lo sagrado fuera una modalidad venerativa más. Por el otro, se ha sostenido que el sometimiento de una sociedad o sector social requiere la desarticulación del entramado de creencias y rituales asociados a lo que sus miembros tienen por sagrado, puesto que esa desactivación lo es de los modelos desde el que se generan y distribuyen significados y valores. En este último caso, la inutilización de lo santificado como eje de estructuración de la experiencia humana puede conducir bien a su sustitución por otro sistema de sacralización que no cuestione el valor de lo natural como vía de acceso a lo sobrenatural, o bien a la denuncia como insensata, atrasada o irracional de tal pretensión, luego de lo cual el lugar y el tiempo que fueron sagrados son dejados vacantes o sustituidos por imitaciones con un papel meramene representativo. Esta última ha sido la lógica de los procesos de desacralización, que establecieron que lo sagrado debía ser expulsado o marginado del nuevo espacio público, puesto que en modo alguno podía aceptársele como fuente de una autoridad extramundana que no podía ser desacatada. Para ello, habilitó todo tipo de sucedáneos civiles de religión con sus respectivas sacralizaciones, pero que a las que ya no se les arrogaba la misión de vehicular la comunicación de y con lo insondable y, tras ello, con el ascendente de fuerzas morales incontrovertibles del todo externas al individuo.

Y he ahí la paradoja. La oposición imaginada como topográfica entre lo sagrado y lo profano fue una constructo conceptual tras el cual la primera sociología francesa invitó a reconocer otro contraste: el de lo colectivo imponiéndose sobre lo individual. Los procesos 
de secularización venían a invertir los términos de ese vínculo: lo sagrado, en el sentido religioso, trasladaba sus oficios y misterios de fuera a dentro, es decir del ámbito de las sensaciones compartidas al de los sentimientos íntimos. Esa privatización de lo santo implicaba, a su vez, que los ritos renunciaban a su virtud como mediadores y ya no asumían otra pretensión que no fuera la de ser meros actos conmemorativos desprovistos de toda eficacia. A medida que iban incorporándose a la modernidad, todas las relaciones sociales, incluyendo las de dominación, pasaron a regularse a partir de códigos y criterios de verdad psíquica, tras los cuales las gravitaciones sociales continuaban ejerciendo su control, ahora desde la conciencia personal de cada cual. Y fue así como la nueva ideología dominante, el laicismo, invitó o forzó a lo sagrado a desaparecer del mundo externo, pero lo hizo para obligarlo a refugiarse en la vivencia personal, en el reino interior del sujeto y su subjetividad, nuevo sagrario de certezas incomunicables que interiorizaban el control social y que cada individuo obedecía convencido de que se obedecía.

\section{BIBLIOGRAFÍA}

Agamben, G. (2005), Profanaciones, Barcelona, Anagrama.

Arbeola, V. M. (1973), Socialismo y anticlericalismo, Madrid, Taurus.

Arce Fustero, G. (2018), De espaldas a Cristo. Una historia del anticlericalisme en Colombia, 1849-1948, Medellín, Editorial Universidad de Medellín.

Aston, M. (1988), England's Iconoclasts, Oxford, Oxford University Press.

Auzépy, M. F. (1987), “L'iconodulie: Défense de l'image ou de la devotion de l'image", en Boesfplug, F. y Lossy, N. (comp.), Nicée II, 787-19 87. Douze siecles d'imagerie religieuse, París, Cerf, 157-164.

Bataille, G. (2007 [1957]), El erotismo, Barcelona, Tusquets.

Bateson, G. y Bateson, M. C. (1989), El temor de los ángeles. Epistemología de lo sagrado, Barcelona, Gedisa, 29-64.

Bajtin, M. (1988 [1965]), La cultura popular en la Edad Media y el Renacimiento. El contexto de François Rabelais, Madrid, Alianza.

Beçanson, A. (2003), La imagen prohibida: Una historia intelectual de la iconoclastia, Madrid, Siruela.

Benjamin, W. (2014 [1921]), El capitalismo como religión, Madrid, La Llama.

Benedict, R. (1938), "Religion”, en Boas, F. (ed.), General Anthropology, Nueva York, Columbia University Press, 627-655.

Beránek, O. y Ťupek, P. (2018), The Temptation of Graves in Salafi Islam. Iconoclasm, Destruction and Idolatry, Edimburgo, Edinburgh University Press.

Bernard, C. y Gruzinski, S. (1993), De la idolatría. Hacia una arqueología de las ciencias de la religión, México DF, FCE.

Blom, P. (2007), Encyclopédie. El triunfo de la razón en tiempos irracionales, Barcelona, Anagrama.

Caillois, R. (2014 [1939]), El hombre y lo sagrado, México DF, FCE.

Crew, Ph. M. (1978), Calvinist Preaching and Iconoclasm in the Neederlanden, 1544-1566, Cambridge, Cambridge University Press.

Cottret, B. (1984), "Pour une sémiotique de la Réforme: Le Consensus Tigurinus (1549) et la Brève résolution... (1555) de Calvin", Annales ESC, 40 (2), 265-285.

Crouzet, D. (1990), Les Guerriers de Dieu. La violence au temps des troubles de religion, París, Champ Vallon, 2 vols.

Cueva, J. de la, (1998): "El anticlericalismo en la Segunda República y la Guerra Civil", en La Parra López, E. y Suárez Cortina, M. (eds.), El anticlericalismo español contemporáneo, Madrid, Biblioteca Nueva, 211-230. 
- $\quad$ (2000), "'Si los curas y frailes supieran...' La violencia anticlerical”, en Juliá, S. (dir.), Violencia política en la España del siglo XX, Madrid, Taurus, 191-233.

Cueva Merino, J. de la, y Montero García, F. (eds.) (2007), La secularización conflictiva. España (1898-1931), Madrid, Biblioteca Nueva.

(2009), Laicismo y catolicismo. El conflicto político-religioso en la segunda república, Alcalá de Henares, Universidad de Alcalá.

De Baets, A. (2014), "The Year Zero: Iconoclastic breaks with the past", Annales Universitatis Paedagogicae Cracoviensis Studia Politologica, 13, 3-18.

Delgado, M. (2012), La ira sagrada. Anticlericalismo, iconoclastia y antirritualismo en la España contemporánea, Barcelona, RBA.

Di Stefano, R. (2010), Ovejas negras. Historia de los anticlericales argentinos, Buenos Aires, Sudamericana.

Durkheim, É. (2006 [1906]), "Determinación del hecho social”, en Sociología y filosofía, Buenos Aires, Schapire, 35-65.

- $\quad$ (2008 [1912]), Las formas elementales de la vida religiosa, Alianza, Madrid.

Davis, N. Z. (1993), "Los ritos de la violencia", en Sociedad y cultura en la Francia moderna, Barcelona, Crítica, 149-185.

Eliade, M. (1981 [1957]), Lo sagrado y lo profano, Madrid, Guadarrama.

Freedberg, D. (2017), Iconoclasia. Historia y psicología de la violencia contra las imágenes, Vitoria-Buenos Aires, Sans Soleil Ediciones.

Hubert, H, y Mauss, M. (2010 [1899]), "Ensayo sobre el sacrificio", en Mauss, M., El sacrificio. Magia, mito y razón, Buenos Aires, Las Cuarenta.

Gamboni, D. (2014), La destrucción del arte: iconoclasia y vandalismo desde la Revolución Francesa, Madrid, Cátedra.

Garrisson Estebe, J. (1975), "The rites of violence: Religious riot in Sixteenth Century France", Past \& Present, 66, 127-150.

Giobellina, F. (2014), El lado oscuro. La polaridad sagrado/profano en Durkheim y sus avatares, Buenos Aires, Katz.

Girard, R. (1983), La violencia y lo sagrado. Anagrama, Barcelona.

Gofmann, E. (2009 [1959]), La presentación de la persona en la vida cotidiana, Buenos Aires, Amorrortu.

Goody, J. (1999), “¿Iconos e iconoclastia en África? Ausencia y ambivalencia”, en Representaciones y contradicciones, Barcelona, Paidós, 51-90.

Grabar, A. (1998), La Iconoclastia bizantina, Madrid, Akal.

Gruzinski, S. (2014), La Colonización de lo imaginario, México DF, FCE.

Gumbrecht, H. U. (2005), Producción de presencia. Lo que el significado no puede transmitir, México DF, Universidad Iberoaméricana.

Habermas, J. (2011), El poder de la religión en la esfera pública, Madrid, Trotta.

Hermant, D. (1978), "Destructions et vandalisme pendant la Révolution française", Annales ESC, 33 (4), 703-719.

Hill, Ch. (2015), El mundo trastornado. El ideario popular extremista en la Revolución inglesa del siglo XVII, Madrid, Siglo XXI.

La Parra López, E. y Suárez Cortina, M. (eds.) (1998), El anticlericalismo español contemporáneo, Madrid, Biblioteca Nueva.

Lalouette, J. (1997), "El anticlericalismo en Francia, 1877-1914", en Cruz, R. (ed.), El anticlericalismo, Madrid, Marcial Pons, (27), 15-38.

Lannon, F. (1990), Privilegio, persecución y profecía. La iglesia católica en España, 18751975, Madrid, Alianza.

Latour, B. (2002), "What is Iconoclash? or Is there a world beyond the image wars?", en 
Weibel, P. y Latour, B., Iconoclash, Beyond the Image-Wars in Science, Religion and Art, Cambridge, ZKM and MIT Press, 14-37.

Ledesma, J. L. (2005), "La 'santa ira popular' del 36: la violencia en guerra civil y revolución, entre cultura y política”, en Muñoz, J., Ledesma, J. L. y Rodrigo, J. (coords.), Madrid, Sierte Mares, 147-192.

Leiris, M. (2007 [1931]), El África fantasmal. De Dakar a Yibuti, 1931-1933, Valencia, Pretextos.

Llobera, J. (1996), El dios de la modernidad. El desarrollo del nacionalismo en Europa occidental, Barcelona, Anagrama.

Luther, M. (2012 [1529]), Grand Catéchisme, Florencia, Nabu Press.

Mannelli, S. (2002), Anticlericalismo e democrazia: Storia del Partito radicale in Italia e a Roma, 1901-1914, Soveria Marelli, Rubbettimo.

Martínez Assad, C. (1991), El laboratorio de la revolución. El Tabasco garridista, México DF, Siglo XXI.

Mellor, A. (1967), Historia del anticlericalismo francés, Bilbao, Mensajero.

Milhazes, J. (2012), "Comunismo como fase suprema do anticlericalismo", Cultura, Espaço \& Memória, 3, 63-78.

Mitchell, T. J. (1988), Violence and Piety in Spanish Folklore, Minesotta, University of Pennsylvania Press.

Mochizuki, M. M. (2006), The Netherlandish Image after Iconoclasm, 1566-1672. Material Religion in the Dutch Golden Age, Londres, Routledge.

Otaola, J. (1999), Laicidad. Una estrategia para la libertad, Barcelona, Bellaterra.

Otto, R. (1980 [1917]), Lo santo. Lo racional y lo irracional en la idea de Dios, Madrid, Alianza.

Philipps, J. (1973), The Reformation of Images: Destruction of Art in England, 1535-1600, Berkeley, University of Berkeley Press.

Prades, J. A. (1998) Lo sagrado. Del mundo arcaico a la actualidad, Barcelona, Península.

Radcliffe-Brown, A. R. (1996 [1939]), "Tabú", en Estructura y función en la sociedad primitiva, Barcelona, Península, 153-173.

Rambelli, F. y Reinders, E. (2012), Buddhism and Iconoclasm in East Asia: A History, Londres/Nueva York, Blombsbury.

Ranzato, G. (1997), "Dies irae. La persecuzione religiosa nella zona republicana durante la guerra civile spagnola (1936-1939)", en La difficile modernità e altri saggi sulla storia della Spagna contemporanea, Turín, Edizioni dell'Orso, 195-220.

Reinders, E. (2004), "Monkey kings make havoc: iconoclasm and murder in the Chinese cultural revolution", Religion, 34, 191-209.

Ríos Figueroa, J. (2002), Siglo XX. Muerte y resurrección de la Iglesia Católica en Chiapas, San Cristóbal de las Casas, UNAM.

Romero, P. G. (2002), El ojo de la batalla. Estudios sobre iconoclastia e iconodulia, historia del arte y vanguardia moderna, Valencia, Col-legi Major Rector Peset.

Sansi, R. (2009), « Intenció i atzar en la historia del fetitxe », Quaderns de l'Institut Català d'Antropologia, 23 (8), 139-158.

Sarró, R. (2009), The Politics of religious change on the Upper Guinea Coast: Iconoclasm done and undone, Edimburgo, Edinburgh University Press.

Simmel, G. (1986 [1908]), "El secreto y la sociedad secreta", en Sociología, Madrid, Alianza, vol. I, 357-424.

Thomas, M. (2014), La Fe y la furia: violencia anticlerical popular e iconoclasta en España, 1931-1936, Granada, Comares. 
Tylor, R. P. (1985), The Death and the Resurrection Show. From Shamanism to Superstars, Londres, Blond.

Ullman, J. C. (2009 [1968]), La Semana Trágica, Barcelona, Ediciones B. 